\title{
VIRULENSI SEJUMLAH ISOLAT XANTHOMONAS AXONOPODIS PV GLYCINES ASAL EDAMAME PADA TIGA VARIETAS KEDELAI
}

\author{
Andi Khaeruni $\mathbf{R}^{1}$, Budi Tjahjono ${ }^{2}$, Antonius Suwanto ${ }^{3}$ dan Meity S. Sinaga ${ }^{2}$
}

\begin{abstract}
Virulence of some Xanthomonas axonopodis pv. glycines Isolates from Edamame on Three Soybean Varieties. Bacterial pustul disease caused by Xanthomonas axonopodis pv. glycines is the most important bacterial disease in soybean cultivation worldwide including in Edamame cultivation in Indonesia. Information of virulence level of this pathogen in Edamame unknown yet. The objective of this research was to evaluate the virulence level of 29 X. axonopodis pv. glycines isolates from Edamame on three soybean varieties (Wilis, Orba and Edamame). The result showed that four isolates (JA7, JA8, JB4 and JB7) were hight virulent. The isolates also have faster laten priodic, higher disease severity as well as the rate epidemic increase in Edamame variety than in both Wilis and Orba varieties.
\end{abstract}

Key words : Xanthomonas axonopodis pv. glycines, virulence level, bacterial pustul disease

\section{PENDAHULUAN}

Penyakit pustul bakteri (bacterial pustule) yang disebabkan oleh Xanthomonas axonopodis pv. glycines (Machmud et al., 1999, Hortman et al., 1999) yang dulu dikenal dengan nama Xanthomonas campestris pv. glycines merupakan penyakit bakterial penting pada kedelei di Indonesia (Semangun, 1991; Machmud, 1999), dan sangat merugikan karena dapat menurunkan produksi kedelai sampai 54\% (Skula, 1994).

Edamame (green vegetable soybean) merupakan salah satu jenis kedelai yang biji mudanya dapat dikonsumsi langsung sebagai makanan cemilan. Komoditas ini semakin diminat untuk dikembangkan di Indonesia dalam skala luas sebagai komoditas eksport sebagaimana yang telah dikembangkan di Jember Jawa Timur, Cipanas dan Ciawi Jawa Barat. Berdasarkan hasil survei pendahuluan yang telah dilakukan, menunjukkan bahwa lokasi pertanaman Edamame tidak luput dari serangan patogen penyebab penyakit pustul bakteri. Informasi tentang keberadaan dan status patogen $X$. axonopodis pv. glycines yang berasal dari Edamame seperti patogenisitas dan virulensinya terhadap varietas kedelai lainnya belum banyak dilaporkan, padahal pengembangan Edamame di Indonesia pada awalnya di kelola oleh perusahaan-perusahaan tertentu yang secara khusus mendatangkan benih dari luar negeri, sehingga sangat memungkinkan terjadinya penyebaran galur-galur baru yang bervirulensi tinggi dari patogen tertentu yang terbawa benih sehingga mempengaruhi produktivitas dan pengembangan tanaman kedelai di Indonesia.

Penelitian ini bertujuan mengetahui tingkat virulensi sejumlah isolat $X$. axonopodis pv. glycines asal Edamame pada varietas Orba, Willis dan Edamame, kedua varietas yang disebut pertama adalah varietas kedelai yang umum ditanam oleh petani di Pulau Jawa.

\section{METODE PENELITIAN}

Pengambilan sampel dan pengamatan keparahan penyakit pustul bakteri di lapangan. Pengambilan sampel dilakukan melalui survei ke beberapa lokasi pertanaman Edamame di Jawa Timur (Jember) dan di Jawa Barat (Cipanas, Ciawi dan Bogor). Pengambilan sampel dilakukan di setiap hamparan pertanaman pada 10 tanaman secara diagonal dengan mengambil beberapa sampel daun yang didiagnosis bergejala penyakit pustul bakteri. Selain pengambilan sampel juga dilakukan pengamatan fase pertumbuhan tanaman dan keparahan penyakit secara visual di lapangan. Keparahan penyakit pustul bakteri di lapangan dikategorikan berat jika lebih dari 50\% tanaman yang menunjukkan gejala pustul, jika tanaman yang bergejala pustul berkisar 20\% hingga $50 \%$ dikategorikan sedang, namun jika tanaman yang

\footnotetext{
${ }^{1}$ Program Studi Ilmu Hama dan Penyakit Tumbuhan, Fakultas Pertanian, Universitas Haluoleo, Kendari, e-mail : akhaeruni@yahoo.com

${ }^{2}$ Departemen Proteksi Tanaman, Fakultas Pertanian, IPB, Jl. Kamper, Kampus IPB Darmaga, Bogor 16680

${ }^{3}$ Depertemen Biologi, FMIPA, Institut Pertanian Bogor
} 
bergejala kurang dari $20 \%$ maka keparahan penyakit dikategorikan ringan.

Isolasi bakteri Xanthomonas axonopodis pv glycines asal Edamame. Daun kedelai Edamame yang terinfeksi penyakit pustul bakteri di Cipanas, Ciawi dan Bogor Jawa Barat, serta Jember, Jawa Timur, diambil dengan cara dipetik, kemudian dibungkus dengan tisu basah lalu dimasukkan ke dalam kantong plastik. Isolasi bakteri dilakukan menurut metode Schaad (1988) yang telah dimodifikasi (Rukayadi, 1995). Isolat bakteri yang diperoleh dimurnikan dengan menggunakan media Yeast-extract Dextrose Calcium carbonate Agar (YDCA) untuk diteliti lebih lanjut. Penyimpanan bakteri dilakukan dengan menambahkan gliserol steril $15 \%$ pada suspensi sel dari media padat untuk disimpan dalam freezer pada temperatur $-20^{\circ} \mathrm{C}$.

Uji patogenisitas. Isolat bakteri yang menampilkan karakteristik koloni Xanthomonas axonopodis pv. glycines diuji patogenisitasnya dengan teknik bioesai kotiledon menurut Hwang et al., (1992) yang telah dimodifikasi oleh Mesak et al., (1994) sebagai berikut:

Biji kedelai yang digunakan adalah varietas Wilis yang diperoleh dari Laboratorium Teknologi Benih Darmaga. Benih-benih kedelai tersebut digulung di dalam kertas stensil ukuran kuarto dan diletakkan pada wadah berpenyangga berisi air, sehingga air akan meresap dan membasahi seluruh kertas stensil. Kotiledon siap digunakan sebelum daun primer membuka penuh atau umur tujuh hari. Kotiledon yang telah dipisahkan dari tanaman induknya dengan menggunakan gunting bersih, direndam di dalam akuades selama lima menit. Selanjutnya dilakukan disinfeksi dengan merendamnya dalam $\mathrm{NaOCl} 0,5 \%$ selama 5 menit. Pembilasan di dalam akuades steril secukupnya selama lima menit dan dilakukan dua kali.

Permukaan kotiledon yang menghadap ke bawah (sisi luar keping biji) diletakkan menghadap ke atas di dalam cawan petri berisi kertas tissu steril. Kotiledon ditusuk pada bagian tengahnya dengan menggunakan piranti berupa susunan lima buah jarum steril yang diikat menjadi satu. Koloni yang diduga $X$. axonopodis pv. glycines yang telah ditumbuhkan pada media YDCA diambil dengan menggunakan tusuk gigi steril dan dioleskan pada bekas luka tusukan.
Kontrol negatif digunakan $X$. axonopodis pv manihotis (Xam) dan kontrol positif digunakan $X$. axonopodis pv. glycines YR32. Kertas tissu pada cawan petri dibasahi dengan penambahan $25 \mathrm{ml}$ akuades steril. Inkubasi dilakukan di dalam ruang bercahaya selama 5 hari. Patogenik atau tidaknya suatu isolat ditentukan berdasarkan persentase jumlah kotiledon yang bergejala kuning klorotik lebih 75\% dari kotiledon yang duji.

Uji virulensi. Isolat-isolat $X$. axonopodis pv. glicines ditumbuhkan dalam media YDCA selama 48 jam. Sel bakteri disuspensikan dengan larutan buffer fosfat hingga konsentrasi sel mencapai $10^{8} \mathrm{cfu} / \mathrm{ml}$ (OD 660 $\mathrm{nm}=0,1)$. Suspensi biakan murni yang diperoleh terlebih dahulu dicampur dengan serbuk karborundum 600 mesh sebanyak 1 gram/liter suspensi dan bahan perata Tween $201 \mathrm{ml} /$ liter suspensi.

Benih Edamame dan kedelai varietas Orba dan Wilis ditanam dalam polybag, dipelihara dalam rumah kasa dan diinokulasi dengan 29 isolat $X$. axonopodis pv. glicines pada umur 14 hari setelah tanam. Setiap isolat bakteri masing-masing diinokulasikan pada empat tanaman pada setiap varietas, sehingga dibutuhkan 116 tanaman per varietas. Inokulasi dilakukan dengan menggunakan alat semprot plastik isi satu liter pada tiga tanaman uji. Jumlah suspensi yang digunakan adalah $10 \mathrm{ml} /$ tanaman. Untuk menjaga agar kelembapan tetap tinggi, tanaman yang telah diinokulasi disungkup dengan plastik transparan yang telah dilubangi pada kedua sisinya

Pengamatan dilakukan terhadap periode laten, keparahan penyakit dan laju perkembangan penyakit. Pengamatan periode laten dilakukan setiap hari sejak inokulasi hingga munculnya gejala awal pada daun, sedangkan pengamatan terhadap keparahan penyakit diamati pada minggu pertama, kedua dan ketiga setelah inokulasi. Pengamatan dilakukan terhadap 6 daun, masing-masing 2 daun bagian bawah, tengah dan atas tanaman uji. Kriteria penilaian yang digunakan merupakan modifikasi dari gejala penyakit bercak yang biasanya terjadi pada tanaman kedelai (Sinclair 1982) berdasarkan nilai keparahan penyakit dengan nilai skoring $0=$ tidak ada serangan, $1=$ bercak pustul $\leq 5 \%$ dari luas daun, $2=$ bercak pustul antara $5<X \leq 15 \%$ dari luas daun, $3=$ bercak pustul antara $15<\mathrm{X} \leq 30 \%$ dari luas daun, $4=$ bercak pustul antara $30<\mathrm{X} \leq 50 \%$ dari luas daun $5=$ bercak pustul $>50 \%$ dari luas daun. Selanjutnya keparahan 
penyakit dihitung dengan menggunakan rumus sebagai berikut :

$$
\text { Keparahan penyakit }=\left[\Sigma\left(n_{i} v_{i}\right) /(\mathrm{NV})\right] \times 100 \%
$$

Townsend dan Hueberger (dalam Unterstenhofer, 1963), dengan $n i$ : jumlah daun yang terserang pada setiap kategori, vi : nilai numerik masing-masing kategori serangan, $\mathrm{Z}$ : nilai numerik kategori serangan tertinggi (nilai 5) $\mathrm{N}$ : Jumlah daun yang diamati. Pengamatan dilakukan pula terhadap laju perkembangan penyakit (r) yang dihitung berdasarkan pada keparahan penyakit tanaman menggunakan rumus van der Plank (1963) :

$$
r=[2.3 /(t j-t i)]\left[\log _{e}(x j / 1-x j)-\log _{e}(x i / 1-x i)\right.
$$

dengan ti : waktu pengamatan awal pada hari ke- $i$, t $j$ : waktu pengamatan berikut pada hari ke-j, xi: keparahan penyakit pada hari ke-i, xj: keparahan penyakit pada hari ke-j. Tingkat virulensi setiap isolat ditentukan dengan skor rata-rata dari semua tanaman contoh pada setiap varietas pada pengamatan terakhir menggunakan kriteria pada Tabel 1.

\section{HASIL DAN PEMBAHASAN}

Lokasi pengambilan sampel dan keparahan penyakit di lapangan. Lokasi pertanaman Edamame selama ini masih terbatas di Pulau Jawa. Selain ditanam dalam skala luas oleh perusahaan tertentu, juga ditanam oleh petani dalam lahan yang terbatas. Pengambilan sampel dan pengamatan di lapangan telah dilakukan di daerah Jember Jawa Timur; Cipanas, Ciawi dan Bogor Jawa Barat. Hasil survei di lapangan di sajikan pada Tabel 2.

Tabel 2 memperlihatkan bahwa pertanaman Edamame masih sangat terbatas, hanya di Kabupaten Jember dan di Ciawi yang telah di tanam dalam skala luas, yang dilakukan oleh perusahaan tertentu untuk kebutuhan lokal dan eksport. Sedangkan di lokasi lain seperti di Cipanas dan Bogor hanya di tanam dalam petak-petak kecil untuk kebutuhan lokal. Terbatasnya penanaman Edamame di Indonesia antara lain disebabkan oleh masih terbatasnya konsumsi komoditas ini bagi masyarakat Indonesia, sehingga pemasarannya juga masih terbatas pada konsumen tertentu.

Hasil pengamatan terhadap keparahan penyakit pustul bakteri di lapangan menunjukkan tingkat serangan ringan sampai sedang, pada umumnya keparahan penyakit tinggi jika lokasi yang dikunjungi sedang dalam musim hujan dan pertanaman dalam fase pertumbuhan generatif dan pada beberapa lokasi seperti di Cipanas dan Jember 2, gejala pustul bakteri telah bercampur dengan penyakit daun kedelai lain seperti karat daun cendawan dan hawar daun bakteri, yang memiliki gejala yang mirip satu sama lainnya.

Tabel 1. Kriteria penentuan tingkat virulensi isolat $X$. axonopodis pv. glycines

\begin{tabular}{cc}
\hline Skor keparahan penyakit & Tingkat virulensi isolat yang diuji \\
\hline $\mathrm{vi}=0$ & Tidak virulen \\
$0<\mathrm{vi} \leq 2$ & Virulensi rendah \\
$2<\mathrm{vi} \leq 3$ & Virulensi sedang \\
$3<\mathrm{vi} \leq 5$ & Virulensi Tinggi \\
\hline
\end{tabular}

Tabel 2. Hasil survei dan pengamatan pertanaman Edamame di lapangan

\begin{tabular}{ccccc}
\hline No & Lokasi & Luas lahan & Fase pertumbuhan & Keparahan penyakit \\
\hline 1. & Cipanas & $0,2 \mathrm{ha}$ & Generatif & Ringan \\
2. & Ciawi 1 & $1,0 \mathrm{ha}$ & Vegetatif & Sedang \\
3. & Ciawi 2 & $3,0 \mathrm{ha}$ & Generatif & Ringan-sedang \\
4. & Bogor & $300 \mathrm{~m}^{2}$ & Generatif & Sedang \\
5. & Jember 1 & $8 \mathrm{ha}$ & Vegetatif & Ringan-sedang \\
6. & Jember 2 & $11 \mathrm{ha}$ & Generatif & Sedang \\
\hline
\end{tabular}


Isolasi, patogenisitas dan virulensi sejumlah isolat Xanthomonas axonopodis pv glycines asal Edamame. Sebanyak 29 isolat bakteri $X$. axonopodis pv. glycines yang berhasil diisolasi dari lokasi pertanaman kedelai Edamame di Cipanas, Ciawi, Bogor dan Jember (Tabel 3).

Semua isolat yang diperoleh pada Tabel 3 tersebut mencirikan $X$. axonopodis pv glycines antara lain koloni berbentuk bulat dengan pinggiran rata, mukoid, permukaan koloni konveks, licin, mengkilat dan berwarna kuning pada media YDCA. Hasil uji fisiologi, biokimia menunjukkan bahwa semua isolat yang diperoleh bereaksi gram negatif, dapat menghidrolisa pati, bersifat oksidatif dan katalase yang positif. Selanjutnya dilakukan uji patogenisitas dengan menggunakan teknik uji bioesai pada kotiledon kedelei. Dari 29 isolat yang diuji ternyata semua isolat tersebut merupakan $X$. axonopodis pv. glycines yang ditunjukkan dengan terbentuknya bercak kuning klorotik pada kotiledon. Bioesai kotiledon yang telah dikembangkan oleh Hwang et al. pada tahun 1992, merupakan salah satu uji patogenisitas $X$. axonopodis pv. glycines yang cepat dan andal dan paling sesuai untuk mengerjakan isolat dalam jumlah yang banyak (Mesak et al., 1994). Metode ini menggunakan kotiledon kedelai varietas Wilis yang berumur lima hari kemudian dilakukan pelukaan dengan menggunakan piranti jarum yang

Tabel 3. Hasil isolasi Xanthomonas axonopodis pv glycines dari Edamame

\begin{tabular}{lccc}
\hline No & Kode isolat & Fase tanaman & Lokasi asal isolat \\
1. & JA1 & Vegetatif & Jember \\
2. & JA2 & Vegetatif & Jember \\
3. & JA3 & Vegetatif & Jember \\
4. & JA4 & Vegetatif & Jember \\
5. & JA5 & Vegetatif & Jember \\
6. & JA6 & Vegetatif & Jember \\
7. & JA7 & Vegetatif & Jember \\
8. & JA8 & Vegetatif & Jember \\
9. & JA9 & Vegetatif & Jember \\
10. & JA10 & Vegetatif & Jember \\
11. & JB1 & Generatif & Jember \\
12. & JB2 & Generatif & Jember \\
13. & JB3 & Generatif & Jember \\
14. & JB4 & Generatif & Jember \\
15. & JB5 & Generatif & Jember \\
16. & JB6 & Generatif & Jember \\
17. & JB7 & Generatif & Jember \\
18. & CP1 & Generatif & Cipanas \\
29. & CP2 & Generatif & Cipanas \\
20. & DM11 & Generatif & Bogor \\
21. & DM12 & Generatif & Bogor \\
22. & DM21 & Generatif & Bogor \\
23. & DM22 & Generatif & Bogor \\
24. & CW12 & Generatif & Ciawi \\
25. & CW22 & Generatif & Ciawi \\
26. & CW32 & Generatif & Ciawi \\
27. & CW41 & Vegetatif & Ciawi \\
28. & CW51 & Vegetatif & Ciawi \\
29. & CW61 & Vegetatif & Ciawi \\
\hline
\end{tabular}


telah disterilkan sehingga memudahkan patogen untuk melakukan proses infeksi. Hasil uji patogenisitas dengan bioesai kotiledon ditampilkan pada Tabel 4.

Uji patogenisitas menunjukkan kejadian penyakit berkisar $82,5 \%$ sampai $100 \%$, dengan patogenisitas tertinggi didapatkan pada isolat JA9, JA10 dan CW51 masing-masing sebesar 100\%, sedangkan patogenisitas terendah sebesar $82,5 \%$ yaitu isolat DM11. Selain uji patogenisitas, juga dilakukan uji virulensi untuk melihat tingkat virulensi
$X$. axonopodis pv glycines yang diperoleh pada beberapa varietas inang. Hasil pengamatan terhadap periode laten, keparahan penyakit dan laju perkembangan penyakit melalui uji virulensi dengan inokulasi ke daun tanaman kedelai varietas Edamame, Orba dan Wilis pada umur 2 minggu setelah tanam ditampilkan pada Tabel 5.

Hasil pengamatan pada Tabel 5 menunjukkan adanya variasi virulensi antara isolat yang diperoleh. Periode laten ke 29 isolat berkisar 5 sampai 13 hari

Tabel 4. Hasil uji patogenisitas dengan esai kotiledon

\begin{tabular}{|c|c|c|c|}
\hline \multirow[t]{2}{*}{ Kode Isolat } & \multicolumn{3}{|c|}{ Patogenisitas pada umur 5 hsi } \\
\hline & Periode laten (hari) & $\mathrm{n} / \mathrm{N}$ & $\%$ \\
\hline JA1 & 3 & $38 / 40$ & 95,0 \\
\hline JA2 & 3 & $38 / 40$ & 90,0 \\
\hline JA3 & 3 & $39 / 40$ & 95,0 \\
\hline JA4 & 3 & $34 / 40$ & 85,0 \\
\hline JA5 & 3 & $34 / 40$ & 85,0 \\
\hline JA6 & 3 & $34 / 40$ & 85,0 \\
\hline JA7 & 3 & $34 / 40$ & 85,0 \\
\hline JA8 & 3 & $37 / 40$ & 92,5 \\
\hline JA9 & 3 & $40 / 40$ & 100 \\
\hline JA10 & 3 & $40 / 40$ & 100 \\
\hline JB1 & 3 & $39 / 40$ & 97,5 \\
\hline JB2 & 3 & $39 / 40$ & 97,5 \\
\hline JB3 & 3 & $39 / 40$ & 97,5 \\
\hline JB4 & 3 & $38 / 40$ & 95,0 \\
\hline JB5 & 3 & $38 / 40$ & 95,0 \\
\hline JB6 & 3 & $34 / 40$ & 85,0 \\
\hline JB7 & 3 & $34 / 40$ & 85,0 \\
\hline CP1 & 3 & $36 / 40$ & 90,0 \\
\hline $\mathrm{CP} 2$ & 3 & $36 / 40$ & 90,0 \\
\hline DM11 & 3 & $33 / 40$ & 82,5 \\
\hline DM12 & 3 & $38 / 40$ & 95,0 \\
\hline DM21 & 3 & $34 / 40$ & 85,0 \\
\hline DM22 & 3 & $35 / 40$ & 87,5 \\
\hline CW12 & 3 & $37 / 40$ & 92,5 \\
\hline CW22 & 3 & $35 / 40$ & 87,5 \\
\hline CW32 & 3 & $37 / 40$ & 100 \\
\hline CW41 & 3 & $35 / 40$ & 85,0 \\
\hline CW51 & 3 & $40 / 40$ & 100 \\
\hline CW61 & 3 & $35 / 40$ & 87,5 \\
\hline YR32 (kontrol +) & 3 & $36 / 40$ & 90,0 \\
\hline Xam (kontrol -) & $*$ & $0 / 40$ & 0,0 \\
\hline
\end{tabular}

Keterangan : $\mathrm{n}=$ jumlah kotiledon yang menimbulkan gejala klorotik kuning,

$\mathrm{N}=$ jumlah kotiledon yang diinokulasi 
Tabel 5. Hasil pengamatan terhadap periode laten, keparahan penyakit dan laju perkembangan penyakit pada tiga varietas kedelai yang diinokulasi dengan sejumlah isolat Xag asal Edamame

\begin{tabular}{|c|c|c|c|c|c|c|c|c|c|}
\hline \multirow{2}{*}{$\begin{array}{l}\text { Kode } \\
\text { Isolat }\end{array}$} & \multicolumn{3}{|c|}{ Edamame } & \multicolumn{3}{|c|}{ Orba } & \multicolumn{3}{|c|}{ Wilis } \\
\hline & PL & $\mathrm{KP}(\%)$ & $\mathrm{r}$ & PL & $\mathrm{KP}(\%)$ & $\mathrm{r}$ & PL & $\mathrm{KP}(\%)$ & $\mathrm{r}$ \\
\hline JA1 & 5 & 24,67 & 0,044 & 7 & 17,40 & 0,042 & 10 & 9,57 & 0,035 \\
\hline JA2 & 5 & 24,67 & 0,044 & 7 & 9,57 & 0,035 & 10 & 9,57 & 0,035 \\
\hline JA3 & 5 & 25,78 & 0,044 & 7 & 24,67 & 0,044 & 10 & 9,57 & 0,035 \\
\hline JA4 & 5 & 18,28 & 0,042 & 10 & 4,57 & 0,035 & 10 & 9,57 & 0,035 \\
\hline JA5 & 5 & 24,67 & 0,044 & 7 & 24,67 & 0,044 & 9 & 9,57 & 0,035 \\
\hline JA6 & 5 & 25,45 & 0,044 & 7 & 25,00 & 0,044 & 10 & 9,57 & 0,035 \\
\hline JA7 & 5 & 44,67 & 0,050 & 7 & 19,67 & 0,043 & 9 & 20,00 & 0,043 \\
\hline JA8 & 5 & 45,89 & 0,050 & 7 & 25,57 & 0,044 & 7 & 26,45 & 0,044 \\
\hline JA9 & 5 & 27,78 & 0,045 & 7 & 20,00 & 0,043 & 9 & 9,57 & 0,035 \\
\hline JA10 & 5 & 28,44 & 0,045 & 7 & 24,44 & 0,044 & 7 & 15,55 & 0,041 \\
\hline JB1 & 5 & 34,44 & 0,046 & 10 & 9,57 & 0,032 & 9 & 9,57 & 0,035 \\
\hline JB2 & 5 & 35,80 & 0,046 & 10 & 9,57 & 0,035 & 9 & 9,57 & 0,035 \\
\hline JB3 & 5 & 24,44 & 0,044 & 10 & 9,57 & 0,035 & 10 & 9,57 & 0,035 \\
\hline JB4 & 5 & 44,67 & 0,050 & 10 & 9,57 & 0,035 & 10 & 9,57 & 0,035 \\
\hline JB5 & 5 & 42,67 & 0,050 & 10 & 9,52 & 0,035 & 10 & 9,00 & 0,034 \\
\hline JB6 & 5 & 42,22 & 0,050 & 9 & 19,90 & 0,042 & 9 & 9,52 & 0,035 \\
\hline JB7 & 5 & 42,22 & 0,050 & 9 & 22,25 & 0,044 & 9 & 9,52 & 0,035 \\
\hline CP1 & 9 & 24,34 & 0,044 & 10 & 4,45 & 0,015 & 10 & 9,52 & 0,035 \\
\hline $\mathrm{CP} 2$ & 5 & 25,55 & 0,045 & 10 & 9,55 & 0,035 & 10 & 12,25 & 0,035 \\
\hline DM11 & 5 & 17,17 & 0,042 & 10 & 9,52 & 0,035 & 10 & 9,00 & 0,034 \\
\hline DM12 & 5 & 18,18 & 0,042 & 10 & 9,52 & 0,035 & 10 & 9,00 & 0,034 \\
\hline DM21 & 5 & 20,00 & 0,043 & 10 & 9,75 & 0,035 & 10 & 9,00 & 0,034 \\
\hline DM22 & 5 & 19,89 & 0,043 & 10 & 12,25 & 0,035 & 10 & 10,15 & 0,036 \\
\hline CW12 & 5 & 33,22 & 0,046 & 10 & 10,25 & 0,035 & 10 & 9,52 & 0,035 \\
\hline CW22 & 5 & 38,44 & 0,046 & 12 & 15,50 & 0,041 & 13 & 9,25 & 0,035 \\
\hline CW32 & 6 & 28,44 & 0,045 & 7 & 17,17 & 0,041 & 10 & 9,55 & 0,035 \\
\hline CW41 & 6 & 28,67 & 0,041 & 10 & 13,55 & 0,040 & 10 & 9,57 & 0,035 \\
\hline CW51 & 5 & 24,44 & 0,044 & 7 & 9,52 & 0,035 & 10 & 9,52 & 0,035 \\
\hline CW61 & 5 & 24,67 & 0,045 & 7 & 10,16 & 0,035 & 10 & 9,57 & 0,035 \\
\hline
\end{tabular}

$\mathrm{PL}=$ periode laten, $\mathrm{KP}=$ keparahan penyakit pada umur 3 minggu setelah inokulasi, dan $\mathrm{r}=$ laju perkembangan penyakit

setelah inokulasi. Periode laten tercepat 5 hari setelah inokulasi umumnya diperoleh pada isolatisolat yang diinokulasikan pada tanaman Edamame, kecuali isolat CW32 dan CW41 ( masing-masing 6 hari) serta CP1 dengan periode laten 9 hari. Sedangkan pada varietas Orba dan Wilis bervariasi dari 7 hingga 13 hari. Isolat CW22 merupakan isolat dengan periode laten terlama yaitu 13 hari setelah inokulasi pada varietas Wilis

Keparahan penyakit yang ditimbulkan setiap isolat yang diinokulasi pada Edamame selalu lebih tinggi dibanding varietas Orba dan Wilis. Keparahan terbesar diperoleh pada isolat JA8 (45,89 \%), menyusul JA7 dan JB4 (44,67 \%). Sementara isolat CP1 dan JA4 yang diinokulasi pada varietas Orba memperlihatkan keparahan penyakit yang terendah hingga akhir pengamatan masing-masing $4,45 \%$ dan $4,57 \%$. Keparahan penyakit tersebut berkaitan dengan laju perkembangan penyakit, sehingga isolat yang menimbulkan keparahan penyakit tinggi juga memiliki laju perkembangan (r) penyakit yang tinggi. Laju perkembangan penyakit tertinggi $(0,050)$ juga 
terdapat pada isolat dari Jember yaitu JA7, JA8, JB4, JB5, JB6 dan JB7 yang diinokulasi pada Edamame (Tabel 5).

Apabila periode laten dikaitkan dengan laju perkembangan penyakit, maka tampak semua isolat yang memiliki periode inkubasi yang panjang juga memiliki laju perkembangan penyakit yang lambat. Persentase keparahan penyakit yang ditimbulkan suatu isolat pada tanaman inang pada waktu tertentu merupakan dasar dari penetapan skor virulensi suatu isolat. Oleh karena itu, semua hubungan antar peubah periode inkubasi dan laju perkembangan penyakit juga berlaku untuk skor virulensi isolat. Data pada Tabel 5 menunjukkan bahwa semakin singkat periode laten, semakin besar keparahan penyakit dan laju perkembangan penyakit dari isolat-isolat yang diuji.

Meskipun ke-29 isolat yang diuji bersifat patogen pada uji kotiledon dan hampir semua isolat dapat menimbulkan penyakit ketika diinokulasikan pada tiga varietas yang diuji, akan tetapi isolat-isolat tersebut memiliki periode laten, keparahan penyakit, laju perkembangan penyakit dan tingkat virulensi yang lebih tinggi pada tanaman Edamame dibanding pada varietas Orba dan Wilis.

Tabel 6 menunjukkan bahwa ketika isolat-isolat Xag diinokulasikan pada Edamame diperoleh 9 isolat yang memiliki tingkat virulensi yang tinggi, sedangkan 20 isolat lainnya memiliki tingkat virulensi yang sedang. Sementara itu pada isolat yang sama ketika diinokulasikan pada varietas Orba hanya memperlihatkan virulensi sedang (11 isolat ) dan rendah (18 isolat), bahkan ketika diinokulasikan ke varietas Wilis hampir semua isolat memiliki tingkat virulensi yang rendah, hanya 4 isolat yang memperlihatkan tingkat virulensi sedang. Hal tersebut mengindikasikan bahwa isolat-isolat tersebut memiliki kesesuaian inang yang lebih baik pada Edamame dibanding dua varietas lainnya, hal ini dapat dipahami karena isolat-isolat yang digunakan memang diisolasi dari sentra pertanaman Edamame di Indonesia.

\section{SIMPULAN}

Xanthomonas axonopodis pv. glycines asal Edamame memperlihatkan variasi virulensi yang berbeda pada varietas Orba, Wilis dan Edamame. Diantara 29 isolat yang diperoleh, isolat-isolat JA7, JA8, JB4, dan JB7 yang berasal dari Jember memiliki tingkat virulensi yang tinggi. Isolat-isolat tersebut memiliki periode laten tercepat, persentase keparahan penyakit dan laju perkembangan penyakit yang lebih tinggi pada varietas Edamame dibanding pada varietas Wilis dan Orba

\section{DAFTAR PUSTAKA}

Hartman, G.L., J.B. Sinclair \& J.C Rupe. 1999. Compendium of Soybean Disease. Ed ke-4 . APS Press.

Hwang, P.L., K.D. Harsono \& P.D. Shaw. 1992. Use of detached soybean cotyledons for testingt pathogenicity of Xanthomonas campestris pv. glycines. Plant Dis 76:182-183.

Machmud, M., H. Jumanto \& M. Sudjadi. 1999. Current progress of research on soybean diseases in Indonesia. Workshop on Soybean Biotecnology for Aluminium Tolerance on Acid Soil and Disease Resistance. Held at Ressearch Institut for Food Crops Biotechnology, Bogor, 14-15 September 1999.

Mesak, F.M., A. Suwanto, B. Tjahjono \& E. Guhardja. 1994. Modifikasi bioesei kotiledon kedelai untuk uji patogenitas Xanthomonas campestris pv. glycines, J. Il. Pert. Indon. 4:7782.

Rukayadi, Y. 1995. Analisis profil DNA genom sejumlah isolat Xanthomonas campestris pv. glycines dengan menggunakan elektroforesis gen medan berpulsa (Pulsed-Field Gel Electrophoresis).[Tesis]. Program Pascasarjana Institut Pertanian Bogor.

Schaad, N.W. 1988. Laboratory Guide for Identification of Plant Pathogenic Bacteria, Ed ke-2. APS Press. St Paul, Minnesot

Sinclair, J.B. 1982. Compendium of Soybean Disease. Ed ke-3 . APS Press. St Paul, Minnesota

Skula, A.K. 1994. Pilot estimation studies of soybean (Glycines max) yield losses by varion levels of bacterial pustule (Xanthomonas campestris pv. glycines) infection. Int. J. Pest Manag. 40:249-251. 
Unterstenhofer, G. 1976. The basic principles of crop protection field trials. Pflanzenshustsnatchrichten Bayer AG. Leverkusen.
Van der Plank, J.E. 1963. Plant Diseases, Epidemic and Control. New York. Academic Press. 